\title{
Progress in Mineral Nutrition and Nutrient Management for Vegetable Crops in the Last 25 Years
}

\author{
George J. Hochmuth \\ Horticultural Sciences Department, North Florida Research and Education Center, University of Florida, Quincy, \\ FL 32351-5677
}

\begin{abstract}
Vegetable production is a very important part of the agricultural industries of most states in the United States, accounting for nearly, or more than, $\$ 1$ billion in states such as California, Florida, Texas, and Arizona. A large part of the success in vegetable culture in this country has been due to the research-based understanding of the mineral nutrition of vegetables and the knowledge about fertilization of these crops for optimum production and crop quality. The establishment of the first state agricultural experiment stations in the late 1880s led to demonstration work on the need for fertilizers in crop production (Havlin et al., 1999). This early demonstration work evolved into a more scientific approach over the early part of the 20th century. Maynard and Lorenz (1979a) reviewed the advances made in vegetable mineral nutrition and fertilization during the first 75 years of the 20th century. During the early part of this period, the understanding of commercial fertilizer manufacturing and fertilizer use on vegetable crops was just developing, with horticultural scientists playing a major role in the research. It was during the first half of the 20th century when most of the micronutrients now known to be essential for crop production were identified (Marschner, 1995). Research in the last 25 years has led to the identification of several nonessential but beneficial elements, including sodium, silicon, cobalt, selenium, and aluminum (Marschner, 1995). In addition, the first half of the 20th century was a time of active development of the processes for manufacturing modern commercial fertilizer materials. The first 75 years of the 20 th century was a time of prolific field research on the optimum fertilizer amounts, scheduling, and placement of fertilizers for best crop productivity (Hochmuth, 2000; Locascio, 1987; Maynard and Lorenz, 1979a).
\end{abstract}

Much of what we understand and practice in vegetable crop fertilization today is based on what was learned and developed in the first 75 years of the 20th century. In the last 25 years much of the research has turned from determining best amounts of fertilizer to use to determining optimum management of those nutrients from crop quality and environmental impact perspectives. Knowledge gained has been incorporated into textbooks used in teaching, for example, a recent book by Decoteau (2000), and into vegetable production recommendation resources such as those presented for several states in Knott's Handbook for Vegetable Growers by Maynard and Hochmuth (1997). The purpose of this paper is to build on the review by Maynard and Lorenz (1979a) by highlighting the advances of vegetable crop nutrition and nutrient management made over the last 25 to 50 years of the 20 th century and taking a look into the 21 st century with respect to vegetable crop nutrition.

\section{FERTILIZER MATERIALS}

FerTilizer formulations. Modern commercial fertilizer materials were in their early stages of development in the latter part of the 19th century and the first part of the 20th century. Fertilizer manufacturers have made mixed fertilizers composed of $\mathrm{N}, \mathrm{P}$, and $\mathrm{K}$ materials for more than 100 years (Havlin et al., 1999). Most of these products were relatively low-analysis fertilizers and many contained significant amounts of organic materials, such as animal manures. In the early part of the 20th century, manufacturing processes, such as the Haber-Bosch process for producing synthetic ammonia, were developed that led to the higher-analysis chemical fertilizers we know today, composed of highly concentrated N, P, and K ingredients. Many of the modern mixed fertilizer materials contain little or no filler or diluent materials because these fertilizer materials are composed of highly concentrated ingredients. The development of soil testing technologies led to the ability to identify individual soil nutrient deficiencies and this, in turn, led to increased use of single-nutrient fertilizers composed of $\mathrm{N}, \mathrm{P}$, or
K. Early manufactured fertilizers were mostly solid materials, but in the middle part of the 20th century, liquid versions of fertilizer materials, particularly $\mathrm{N}$, became available and their use increased rapidly in the latter quarter of the 20th century. The liquid materials, containing $\mathrm{N}$ and $\mathrm{P}$, were very useful as vegetable transplant starter fertilizers, and the liquid $\mathrm{N}$ materials were used as easily-applied sidedress fertilizers. During the last 25 years, many advances have been made in the formulation of mixed-nutrient liquid fertilizers, many containing most of the essential nutrients for plant growth. The major factors driving the development of liquid fertilizers include the ease and uniformity of application, the advent of drip irrigation and fertigation (the application of nutrients with the irrigation system), and the development of modern hydroponic and greenhouse vegetable production systems. Drip irrigation and greenhouse vegetable production will be discussed later in this paper.

Fertilizer Sources. Over the last 25 years there were numerous researchers evaluating fertilizer sources for specific nutrients for vegetable crops, for example the work by Locascio et al. ( 1981) and Locascio and Martin (1985). Much of the work focused on N fertilizers, but there also has been considerable work on $\mathrm{P}, \mathrm{K}$, and micronutrient sources. The researchers had to account for the possibility of responses to associated nutrients supplied with the nutrient of interest. For example, potential crop responses to $\mathrm{S}, \mathrm{Ca}$, or $\mathrm{K}$ had to be considered in $\mathrm{N}$-source studies involving $\mathrm{CaNO}_{3}, \mathrm{NH}_{4} \mathrm{SO}_{4}$, and $\mathrm{KNO}_{3}$. In most studies with most vegetables, there were negligible crop responses to $\mathrm{N}$ source so that most sources can be recommended for vegetable culture and the choice may depend on cost.

CONTROLLED-RELEASE FERTILIZERS AND NITRIFICATION INHIBITORS. Vegetable researchers soon developed a wealth of knowledge about crop nutrient needs, especially $\mathrm{N}$, but the management aspects of fertilization have always been vexing problems. Most chemical fertilizer materials developed in the first half of the century were soluble in the moist vegetable production soil, and rainfall often leached nutrients, especially N, away from the root zone. Researchers helped farmers address this issue by developing split-application schedules for these soluble nutrients, but this approach was not always adequate to prevent $\mathrm{N}$ losses due to untimely rainfall. One technology addressing the need for controlling the availability of nutrients, especially $\mathrm{N}$, to the plant is controlled-release fertilizer (CRF), also sometimes called slow-release fertilizer (Maynard and Lorenz, 1979b). The basic idea was to develop a fertilizer delivery product that could supply most or all of the crop's seasonal nutrient need with one fertilizer application at the beginning of the season. One early idea consisted of coating a fertilizer material, often an $\mathrm{N}$ material such as urea, with a material that reduced the solubility of the fertilizer pellet. The coated $\mathrm{N}$ pellet slowly decomposed in the soil, releasing the $\mathrm{N}$ over a period of time, with the thickness of the coating usually determining the release period. An example of an early CRF was sulfur-coated urea, developed by TVA in 1961, which has been used in vegetable and strawberry production. Considerable field research has been conducted with sulfur-coated urea as a $\mathrm{N}$ fertilizer for vegetables in Florida (Locascio and Fiskell, 1979; Locascio et al., 1978). Early CRFs were an improvement in nutrient management in the field, but still the release of nutrients was difficult to predict, especially under variable soil and climatic conditions. Further advances in CRF materials were made in the last 25 years as fertilizer manufacturers learned to coat the fertilizer materials with water-resistant polymers such as polyurethane, polyethylene, and polyolefin. Most of these materials focused on $\mathrm{N}$, but some contained mixed fertilizers. The mixed-fertilizer materials are largely used in the greenhouse and nursery container-plant industries, although CRF use has increased in field vegetable (especially tomato and pepper) and strawberry production. The type and thickness of the 


\begin{tabular}{|c|c|c|c|c|c|}
\hline \multirow[b]{2}{*}{ Element } & \multicolumn{5}{|c|}{ Soil test interpretation (soil test index in $\mathrm{mg} \cdot \mathrm{kg}^{-1}$ ) } \\
\hline & Very low & Low & Medium & High & Very high \\
\hline$\overline{\mathrm{P}}$ & $<10$ & $10-15$ & $16-30$ & $31-60$ & $>60$ \\
\hline $\mathrm{K}$ & $<20$ & $20-35$ & $36-60$ & $61-125$ & $>125$ \\
\hline $\mathrm{Mg}$ & $<10$ & $10-20$ & $21-40$ & $41-60$ & $>60$ \\
\hline $\mathrm{Ca}$ & $<100$ & $100-200$ & $201-300$ & $301-400$ & $>400$ \\
\hline
\end{tabular}

${ }^{\mathrm{z}}$ After Hochmuth and Hanlon (2000) and Simonne and Hochmuth (2002).

polymer coating and soil temperature are factors determining the rate of $\mathrm{N}$ release and length of the release period for these types of CRF products. As the economics of CRF use becomes more favorable and as their field performance becomes more predictable, CRFs might have an important role to play in future vegetable crop nutrient best management practices (BMPs).

Another approach to reducing $\mathrm{N}$ losses in crop production was the use of nitrification inhibitors, which reduce the conversion of ammonium-N to nitrate-N, the form of $\mathrm{N}$ most likely to leach in most soils. Research with nitrification inhibitors was done with products such as nitrapyrin (2-chloro 6-trichloromethyl pyridine) and DCD (dicyandiamide) (Frye et al., 1989; Hendrickson et al., 1978; Welch et al., 1985). These products have not yet received widespread commercial use with most vegetable crops.

\section{FERTILIZER AND NUTRIENT MANAGEMENT}

SOIL TESTING AND FERTILIZER RECOMMENDATIONS. Considerable research effort has been expended in the 20th century for determining optimum amounts of fertilizers for vegetables. Most of the work involved evaluations of crop response to added fertilizer amounts thought to capture the probable range of response to a nutrient. Most of our current state extension vegetable fertilizer recommendations came from research in the first 75 years of the 20th century. Recently more attention has turned to refining the fertilizer recommendations, with more attention to improved experimental and statistical approaches to studying agronomic crop responses to fertilizers (Black, 1993; Cerrato and Blackmer, 1990; Colwell, 1994; Dahnke and Olson, 1990). Examples of the use of these statistical approaches to evaluating vegetable fertilizer responses include work with watermelon (Hochmuth et al., 1993a) and lettuce (Sanchez et al., 1990; Willcutts et al., 1998).

Scientists in the 1970s and 1980s were active in developing and calibrating soil testing technologies for use in making fertilizer recommendations for vegetable crops (Dahnke and Olson, 1990). There are various philosophies for making recommendations for crop fertilization, including the basic-cation-ratio approach, the soil-nutrient maintenance approach, and the nutrient-sufficiency approach. The sufficiency approach is mostly used by the Land Grant Universities, while the other philosophies are subscribed to by most commercial soil testing laboratories. An interesting study conducted in Nebraska compared these philosophies with regard to fertilization of corn and the resulting economics (Olson et al., 1982). The sufficiency approach resulted in the most economical approach to fertilization because it recommended addition only of the amount of nutrients needed to supplement the nutrition supplied by the unfertilized soil. The results illustrated the importance of incorporating soil testing research results in the fertilizer recommendation process. Many soil testing calibration studies were conducted with vegetables in Florida by researchers in the 1980s and 1990s. These workers calibrated the Mehlich 1 soil test extractant (Hochmuth et al., 1993c; Mehlich, 1953) for use in making P, K, Ca, and $\mathrm{Mg}$ recommendations with sandy soils (Table1). Calibrating a soil test for $\mathrm{K}$, a relatively mobile nutrient in sandy soils, proved to be more problematic (Hochmuth et al., 1993b). Properly calibrated soil testing extractants can predict situations where responses to nutrients, such as $\mathrm{P}$, are unlikely and growers can therefore refrain from $\mathrm{P}$ fertilization. This aspect of a soil test is critical for farmers producing vegetables in environmentally sensitive areas. Researchers found difficulty using soil testing to make fertilizer recommendations for $\mathrm{N}$ in sandy soils in Florida's humid climate. In contrast, under less humid climates, the pre-sidedress nitrate test was effective in predicting situations where sidedress N fertilizer was (or was not) needed (Krusekopf et al., 2002; Magdoff et al., 1990). Considerable research has been conducted in
California in commercial vegetable fields to demonstrate the utility of soil nitrate tests (Hartz, 1994; Hartz et al., 1993b). Vegetable researchers working with soil-testing methods have shown that optimum vegetable nutrient management in the 21 st century will depend on properly field calibrated and tested soil-testing methodologies.

Efforts at controlling nutrient losses in soils were bolstered greatly in the $1950 \mathrm{~s}$ with the commercialization of polyethylene (plastic) mulch as a soil cover for vegetable culture (Emmert, 1957). Although plastic mulch was developed as a growth-enhancing practice that led to earlier and more profitable crops, researchers also noted that plastic mulch placed over the fertilized soil retarded the loss of soil-mobile nutrients such as $\mathrm{N}$ (Locascio, 1961). Researchers in humid production climates, such as Florida, determined methods to place fertilizer under plastic mulch in one application, lasting the season. Leaching of fertilizer can still occur under plastic mulch, especially under high water table production areas such as southern Florida. In these situations, it might be better to use split-applications of nutrients with a liquid fertilizer injection wheel, a unique liquid fertilizer applicator specifically developed for applying fertilizer through the plastic mulch (Csizinszky et al., 1987). Plastic mulch, in the early years, was an expensive input for some vegetable producers, so researchers developed the strip-mulch system where a narrow strip of plastic mulch was used solely to cover and protect the fertilizer band from leaching due to rain or sprinkler irrigation (Hayslip and Iley, 1966). Although the strip-mulch system was effective in its intended role, the cost of full-bed plastic mulch soon became widely acceptable to vegetable growers. Vegetable producers rapidly adopted full-bed plastic mulch, largely benefiting from the enhanced crop growth characteristics, but also benefiting from the nutrient retention afforded by the mulch. In the 1980s, sprayable-mulch (latex mulch) was developed as an alternative to the plastic strip-mulch system, but the sprayable mulch technology has not been widely adopted yet. Full-bed plastic mulch has been adopted widely across the United States and worldwide for vegetable production and it is estimated that there are about 30,000 ha of vegetables and strawberries in Florida and perhaps more than 100,000 ha nationally produced with plastic mulch.

DrIP IRRIGation. The development of drip-irrigation technology in 1961 by R. Chapin in New York, V. Hansen in Denmark, and S. Blass in Israel (Chapin, 1969; Hall, 1971) opened the doors for the greatest advancement in fertilizer management for vegetables. Early work, for example in Israel (Bar-Yosef, 1977), Florida (Locascio et al., 1977; Myers and Harrison, 1973), and California (Phene and Beale, 1976; Phene et al., 1979), formed some of the basis for the drip-irrigation water-management technology we use today. Drip irrigation led to

Table 2. Benefits and challenges of drip irrigation as identified in a survey of extension specialists in southeastern and mid-Atlantic states of the U.S. ${ }^{2}$

\begin{tabular}{clc}
\hline Ranking & Respondents (\%) \\
\hline Drip irrigation benefit & \\
1 & Water conservation & 95 \\
2 & Better fertilizer management & 60 \\
3 & Higher yields/quality & 50 \\
4 & Better disease control & 35 \\
4 & More convenient & 35 \\
Drip irrigation challenge & \\
1 & Expensive to install & 55 \\
2 & Emitter clogging & 45 \\
2 & Filtration needed & 45 \\
3 & Tendency to overwater & 30 \\
3 & Lack of available technical advice & 30 \\
3 & Disposal problems & 30 \\
4 & Need for increased management & 20 \\
4 & Insect/animal damage & 20 \\
\hline
\end{tabular}

${ }^{2}$ After Hochmuth (1994b). 
improvements in water application efficiencies and reduced irrigation amounts for many vegetables by $50 \%$ to $70 \%$ (Clark, 1992). Water conservation (Table 2) was cited as the most important reason for using drip irrigation in the southeastern and mid-Atlantic states of the U.S. (Hochmuth, 1994b). The reduction in water application has had positive implications for nutrient efficiencies, especially $\mathrm{N}$, since $\mathrm{N}$ fertilizer efficiency is closely related to irrigation efficiency, especially in sandy soil production areas (Hochmuth, 1992b, 2000). Fertilizer application efficiencies increased when fertilizer materials could be injected into the drip irrigation system, a process referred to as fertigation. Soluble nutrients such as $\mathrm{N}$ and $\mathrm{K}$ are most often applied by drip irrigation by injecting small amounts of nutrients through the season according to seasonal crop nutrient requirements. Excessive irrigation or fertigation can increase N leaching losses (Pier and Doerge, 1995; Thompson and Doerge, 1995). Schedules for injecting N and K were developed in Florida and other southeastern U.S. states for vegetables (Cook and Sanders, 1991; Hochmuth, 1992a; Locascio et al., 1985; Locascio and Martin, 1985; Locascio and Smajstrla, 1989). Fertigation set the stage for vegetable growers to meet the challenges of the nutrient BMPs being called for by environmental agencies in many states.

Tissue Testing. The latter part of the 20th century saw the advancement in laboratory technologies for determining elemental concentrations in plant tissues. Techniques such as plasma emission spectroscopy, with simultaneous determination of many elements (Blakemore and Billedeau, 1981; Ward et al., 1980), have greatly improved laboratory capacity. Turn-around time in most commercial analytical labs can be as short as 1 day, greatly improving the diagnostic capability of modern extension agents and consultants. Researchers in several states have developed tissue testing recommendations and interpretations for vegetable crops (Hochmuth et al., 1991; Reisenauer, 1983). New petiole sap quick-test technologies have further increased the facility of plant nutrient determinations. Plant sap testing has a long history, going back 70 years (Carolus, 1935; Emmert, 1934), but new methods have greatly improved the ease with which the technique can be used on the farm. Early research with petiole sap testing using colorimetric quicktests was conducted in Great Britain by Prasad and Spiers (1985) and then in Hawaii by Coltman (1987). Researchers in Florida calibrated a colorimetric technique for several vegetables (Hochmuth, 1994a). More recently those same researchers calibrated hand-held, battery-operated, ion-specific meters for $\mathrm{N}$ and $\mathrm{K}$ with vegetable petiole sap (Hochmuth et al., 1993c; Rhoads et al., 1996). Techniques were standardized for sample handling and measurement. Work with potato petiole sap also was conducted in Minnesota (Rosen et al., 1996) and for vegetables in California (Hartz et al., 1993a). With standard laboratory techniques, costs and turn-around time for the results kept many growers from taking advantage of routine tissue testing for $\mathrm{N}$ and $\mathrm{K}$ in the season. The ease and economics of petiole sap testing has made it possible for growers to test their crops routinely in the season and anticipate fertilization problems that might lead to crop loss.

RELATIONSHIP OF FERTILIZATION AND VEGETABLE QUALITY. Early fertilization experiments in the 20th century showed the benefits of fertilization for increased yields and improved crop value. Improved crop value resulted from increased yields and improved vegetable size, shape, color, or other quality factors. Few reports determined the effects of fertilization on vegetable quality over a range of deficiency to excessive amounts of nutrients. In most cases, fertilization improved vegetable quality and yield simultaneously, and growers often claim that their use of excessive rates of nutrients is to ensure production of the best quality in their vegetables. However, there are several examples in Florida where excessive amounts of fertilizer led to decreased vegetable quality. In chipping potato, high tuber specific gravity, a quality parameter in chipping potatoes, was reduced with excessive $\mathrm{K}$ fertilization (Locascio et al., 1991, 1992). Strawberry fruit size responded quadratically to $\mathrm{N}$ rate, with fruit size decreasing once the optimum rate of $\mathrm{N}$ for fruit yield was reached (Hochmuth et al., 1996). Carrot quality parameters of sugar and carotene contents likewise decreased as rates of $\mathrm{N}$ increased over the rate needed for greatest carrot yield (Hochmuth et al., 1999). These research experiences illustrated that proper crop fertilization not only involves optimum yields but also plays a role in determining greatest vegetable quality.

GreEnHOuse FERTILIZATION. Greenhouse vegetable culture with soilless systems is important around the world. Greenhouse culture can be practiced in climates that are not conducive to field culture and in areas without suitable soil. Soilless systems will be more important as soil fumigants, such as methyl bromide, become scarce or too expensive for outdoor field vegetable production. In the last 25 years, there have been major advances in greenhouse production systems, including rockwool and perlite media, and in fertilization of greenhouse vegetables. Considerable information on nutrition of commercial greenhouse vegetable production has been written for crops growing in nutrient film technique and in soilless culture systems, especially in Florida. For example, Schon et al. (1994) determined N fertilization programs for pepper and cucumber growing in rockwool in Florida greenhouses. Fertilizer formulae for tomato culture in rockwool and perlite in Florida were developed by Hochmuth (1991).

NuTRIENT BMPs. If the first 75 years of the 20th century can be described as the era of fertilizer materials development and application for vegetable crop growth, the last 25 can be described as the period of emphasis on fertilizer management. Much of the research early in the century concentrated on determining the best source and amount of fertilizer for vegetable yields, without much attention paid to the ultimate fate of crop nutrients in the environment. Fertilizer has been relatively inexpensive compared to other crop production inputs such as pest control and labor. Vegetable growers had learned the advantages of crop fertilization in terms of increased yields, so they were likely to err on the side of too much fertilizer to minimize the risk associated with reduced yields if inadequate fertilizer amounts were used. Researchers today concentrate on defining methods for fertilization that result in the greatest crop production with the least amount of fertilizer and with the least negative impact on the environment.

\section{GLIMPSE INTO THE FUTURE}

Research in the 20th century has mostly determined the amounts of nutrients needed for optimum vegetable production. Some might argue that there are still researchable aspects to determining rates for some specialty vegetables, but for the most part, we have a good idea of the general amounts of fertilizer it takes to produce most vegetables. In the 21 st century, the emphasis will be on producing economical yields with reduced fertilizer inputs. Availability of certain easily mined nutrients, such as $\mathrm{P}$, is predicted by some to nearly expire in the 21 st century. Reduced availability of expensive nutrients demands that the most efficient fertilization technologies be developed and implemented. In many states, agriculture is implicated in the nutrient enrichment of surface water bodies and groundwater. Considerable effort is being marshaled in many states to implement nutrient BMPs for crop production with legislated rules and incentive programs. In the future, emphasis must be placed on defining the set of crop production technologies to use in certain production settings to achieve the greatest protection of the environment while providing for profitable vegetable production. For example, in a dry climate, a nutrient BMP set for watermelon production might include a calibrated soil test extractant for $\mathrm{P}$ fertilization, soil nitrate determination for $\mathrm{N}$ fertilization, drip irrigation, and fertigation of N. In more humid climates, the BMP list might include a calibrated soil test extractant for $\mathrm{P}$, plastic mulch, drip irrigation, and fertigation of $\mathrm{N}$.

Nutrient management in the 21 st century will rely increasingly on computer models and satellite-based technologies such as precision nutrient management (Soil and Plant Analysis Council, 1994). The precision approach to nutrient management has been well developed for commercial use for agronomic crops grown on an extensive scale. However, precision nutrient management approaches have not been widely adopted yet in vegetable production. In the future, precision approaches to nutrient management will be important as vegetable producers look for more cost efficiency in production and as they adopt nutrient BMPs.

The terms production systems and high-tech will become even more commonplace in reference to vegetable production. With the reduced availability of certain soil pesticides and fumigants and the need to become more nutrient management efficient, growers will be taking increasing advantages of new (and old) techniques of crop management, including increased use of rotation, intercropping, double cropping, and 
other strategies. Growers will become more familiar with managing the soil organic matter, nutrients, fauna, and flora for maximizing crop production and quality. Farmers will increasingly look for productionsystems approaches that provide year-round income on the farm, and these production systems must provide for increased nutrient management capabilities. For many farms, the future will be in crop and enterprise diversity. Vegetable producers are constantly looking for new crops and alternative crops and production systems to meet a particular marketing niche. With the increasing ethnic populations in the U.S., many vegetable producers are turning to specialty ethnic crops to meet the demand of an increasingly diverse U.S. population. There has been increased interest in organic crop production. Nutrient management and fertilization techniques will be needed for these new crops and alternate production systems. Reduced availability of the best land for vegetable production (due to urbanization) will place increased pressure on farmers to make the most efficient use of the available land. Vegetable farmers will turn increasingly to more intensive production technologies such as greenhouses and polyethylene tunnels, which allow them to meet the challenges of year-round vegetable production in harsher climates. These more intensive production systems might mean more nutrient use per unit of land area, and, hence, efficient nutrient use will be required in the production systems. Efficient nutrient handling technologies, including nutrient capture and recycling, are already being designed for these greenhouse and intensive production systems.

One overlooked area of research has been the area of breeding crops for nutrient efficiency. Certain genes and gene systems have been identified that contribute nutrient efficiency in some crops and control certain nutrient disorders, but their incorporation into nutrient-efficient varieties has been slow. Much of the pioneering work in the genetics of vegetable plant mineral nutrition was conducted in the 1960s through the 1980s at the University of Wisconsin by Warren Gabelman and Gerald Gerloff (Sussman and Gabelman, 1989). These researchers and their students found genetic variation for N, P, and K mineral nutrition in several vegetable species, including snap bean and tomato. In most cases the genetic basis of the nutrient efficiency was quantitative in nature. Nutrient efficiency was often related to increased efficiency in dry matter production. These studies should be used in the future as the basis for vegetable breeding programs to incorporate nutrient efficiency in varieties that will be grown with reduced fertilizer amounts.

\section{SUMMARY}

Horticulturists have played a very important role in providing vegetable producers the latest in nutrient management information and technologies. Vegetable productivity has increased greatly due to the combined efforts of researchers, industry workers, and farmers in finding and developing efficient production practices. Fertilization and nutrient management have received a large part of this attention in the past. A look into the future reveals an increased need for this cooperation to continue, with emphasis on developing nutrient management technologies that meet farmers' needs for efficient and profitable crop production, meet the consumer's demands for high-quality vegetables, and accomplish all in concert with the need for protecting our environment.

\section{Literature Cited}

Bar-Yosef, B. 1977. Trickle irrigation and fertilization of tomatoes in sand dunes. Water, N, and distribution in the soil and uptake by plants. Agron. J. 69:486-491.

Black, C.A. 1993. Soil fertility evaluation and control. Lewis Publ., Boca Raton, Fla.

Blakemore, W.E. and S.M. Billedeau. 1981. Analysis of laboratory animal feed for toxic and essential elements by atomic absorption and inductively coupled argon plasma emission spectrometry. J. Assn. Off. Anal. Chem. 44:1284-1290.

Carolus, R.L. 1935. Experiences with rapid chemical tests for the determination of nutrient deficiencies in vegetable crops. Proc. Amer. Soc. Hort. Sci. 33:579-583.

Cerrato, M.E. and A.M. Blackmer. 1990. Comparison of models for describing corn yield response to nitrogen fertilizer. Agron. J. 82:138-143.

Chapin, R.D. 1969. Plastic watering systems for greenhouses and field crops.
Proc. Agr. Plastics Conf. 9:138-154.

Clark, G.A. 1992. Drip irrigation management and scheduling for vegetable production. HortTechnology 2:32-37.

Coltman, R.R. 1987. Sampling considerations for nitrate quick tests of greenhouse-grown tomatoes. J. Amer. Soc. Hort. Sci. 112:922-927.

Colwell, J.D. 1994. Estimating fertilizer requirements. CAB Intl. Wallingford, U.K.

Cook, W.P. and D.C. Sanders. 1991. Nitrogen application frequency for drip irrigated tomatoes. HortScience 26:250-252.

Csizinszky, A.A., D.N. Maynard, G.J. Hochmuth, and F.G. Martin. 1987. Supplemental fertilization of cucurbits growing in full-bed polyethylene mulch culture. J. Plant Nutr. 10:1479-1488.

Dahnke, W.C. and R.A. Olson. 1990. Soil test correlation, calibration, and recommendations, p. 45-71. In: R.L. Westerman. (ed.). Soil testing and plant analysis. 3rd ed. Soil Sci. Soc. Amer., Madison, Wis.

Decoteau, D.R. 2000. Vegetable crops. Prentice Hall. Upper Saddle River, N.J.

Emmert, E.M. 1934. Tests for nutrients in conducting tissue as indicators of the nutritional status in horticultural crops. Proc. Amer. Soc. Hort. Sci. 32: 604-609.

Emmert, E.M. 1957. Black polyethylene for mulching vegetables. Proc. Amer. Soc. Hort. Soc. 69:464-469.

Frye, W.W., D.A. Graetz, S.J. Locascio, D.W. Reeves, and J.T. Touchton. 1989. Dicyandiamide as a nitrification inhibitor in crop production in the southeastern USA. Commun. Soil. Sci. Plant Anal. 20:1969-1999.

Hall, B.J. 1971. Comparison of drip and furrow irrigation for market tomatoes. Proc. 10th Natl. Agr. Plastics Conf. 10:19-27.

Hartz, T.K. 1994. A quick test procedure for soil nitrate-nitrogen. Commun. Soil Sci. Plant Anal. 25:511-515.

Hartz, T.K., M. LeStrange, and D.M. May. 1993a. Nitrogen requirements of drip-irrigated pepper. HortScience 28:1097-1099.

Hartz, T.K., R.F. Smith, M. LaStrange, and K.F. Schulbach. 1993b. On-farm monitoring of soil and crop nitrogen status by nitrate-selective electrode. Commun. Soil Sci. Plant Anal. 24:2607-2615.

Havlin, J.L., J.D. Beaton, S.L. Tisdale, and W.L. Nelson. 1999. Soil fertility and fertilizers: An introduction to nutrient management. 6th ed. Prentice Hall.

Hayslip, N.C. and J.R. Iley. 1966. Use of plastic strips over fertilizer bands to reduce leaching. Proc. Fla. State Hort. Soc. 79:132-139.

Hendrickson, L.L., D.R. Keeney, L.M. Walsh, and E.A. Liegel. 1978. Evaluation of nitrapyrin as a means of improving $\mathrm{N}$ efficiency in irrigated sands. Agron. J. 70:699-703.

Hochmuth, G. (ed.). 1991. Florida greenhouse vegetable production handbook, vol. 3. Fla. Coop. Ext. Serv. SP-48.

Hochmuth, G.J. 1992a. Fertilizer management for drip-irrigated vegetables in Florida. HortTechnology 2:27-32.

Hochmuth, G.J. 1992b. Concepts and practices for improving nitrogen management for vegetables. HortTechnology 2:121-125.

Hochmuth. G.J. 1994a. Sufficiency ranges for nitrate-nitrogen and potassium for vegetable petiole sap quick tests. HortTechnology 4:218-222.

Hochmuth, G.J. 1994b. Current status of drip irrigation for vegetables in the southeastern and mid-Atlantic United States. HortTechnology 4:390-393.

Hochmuth, G.J. 2000. Management of nutrients in vegetable production systems in Florida. Soil Crop Sci. Soc. Fla. Proc. 59:11-13.

Hochmuth, G.J., E.E. Albregts, C.C. Chandler, J. Cornell, and J. Harrison. 1996. Nitrogen fertilization requirements of drip-irrigated strawberries. J. Amer. Soc. Hort. Sci. 121:660-665.

Hochmuth, G.J., J.K. Brecht, and M.J. Bassett. 1999. Nitrogen fertilization to maximize carrot yield and quality on a sandy soil. HortScience 34: 641-645.

Hochmuth, G.J. and E.A. Hanlon. 2000. IFAS standardized fertilizer recommendations for vegetable crops. Fla. Coop. Ext. Serv. Cir. 1152. http: //edis.ifas.ufl.edu/CV002.

Hochmuth, G.J., E.A. Hanlon, and J. Cornell. 1993a. Watermelon phosphorus requirements in soils with low Mehlich-1-extractable phosphorus. HortScience 28:630-632.

Hochmuth, G., E. Hanlon, B. Hochmuth, G. Kidder, and D.N. Hensel. 1993b. Field fertility research with $\mathrm{P}$ and $\mathrm{K}$ for vegetables-interpretations and recommendations. Soil Crop Sci. Soc. Fla. Proc. 52:95-101.

Hochmuth, G.J., R.C. Hochmuth, M.E. Donley, and E.A. Hanlon. 1993c. Eggplant yield in response to potassium fertilization on sandy soil. HortScience 28:1002-1005.

Hochmuth, G.J., D.N. Maynard, C.S. Vavrina, and E.A. Hanlon. 1991. Plant tissue analysis and interpretation for vegetable crops in Florida. Fla. Coop. Ext. Serv. Spec. Ser. SS-VEC-42.

Krusekopf, H.H., J.P. Mitchell, T.K. Hartz, D.M. May, E.M. Miyao, and M.D. Cahn. 2002. Presidedress soil nitrate testing identifies processing tomato fields not requiring sidedress $\mathrm{N}$ fertilizer. HortScience 37:520-524.

Locascio, S.J. 1961. The retention of nutrients as affected by plastic mulch. 
Proc. Natl. Agr. Plastics Congr. 2:21.

Locascio, S.J. 1987. Progress in nutrition of Florida vegetables during the past 100 years. Proc. Fla. State Hort. Soc. 100:398-405.

Locascio, S.J., J.A. Bartz, and D.P. Weingartner. 1991. Potato yield and soft rot potential as influenced by calcium and potassium fertilization. Proc. Fla. State Hort. Soc. 104:248-253.

Locascio, S.J., J.A. Bartz, and D.P. Weingartner. 1992. Calcium and potassium fertilization of potatoes grown in north Florida. Amer. Potato J. 69: 95-104.

Locascio, S.J. and J.G.A. Fiskell. 1979. Pepper response to sulfur-coated urea, mulch, and nitrogen rate. Proc. Fla. State Hort. Soc. 92:112-115.

Locascio, S.J., J.G.A. Fiskell, and F.G. Martin. 1978. Comparison of sulfurcoated and uncoated urea for watermelons. Soil Crop Sci. Soc. Fla. Proc. $37: 197-200$.

Locascio, S.J., J.G.A. Fiskell, and F.G. Martin. 1981. Responses of bell pepper to nitrogen sources. J. Amer. Soc. Hort. Sci. 106:628-632.

Locascio, S.J., R.S. Mansell, H.M. Selim, L.C. Hammond, and J.M. Myers. 1977. Nutrient and water distribution in sandy soil during growth of trickleirrigated strawberries. Soil Crop Sci. Soc. Fla. Proc. 36:197-213.

Locascio, S.J. and F.G. Martin. 1985. Nitrogen source and application timing for trickle-irrigated strawberries. J. Amer. Soc. Hort. Sci. 110:820-823.

Locascio, S.J., S.M. Olson, F.M. Rhoads, C.D. Stanley, and A.A. Csizinszky. 1985. Water and fertilizer timing for trickle-irrigated tomatoes. Proc. Fla. State Hort. Soc. 98:237-239.

Locascio, S.J. and A.G. Smajstrla. 1989. Drip-irrigated tomato as affected by water quantity and N and K timing. Proc. Fla. State Hort. Soc. 102:307-309.

Magdoff, F.R., W.E. Joleka, R.H. Fox, and G.F. Griffin. 1990. A soil test for nitrogen availability in the northeastern United States. Commun. Soil Sci. Plant Anal. 21:1103-1115.

Marschner, H. 1995. Mineral nutrition of plants. 2nd ed. Academic Press, San Diego, Calif.

Maynard, D.N. and G.J. Hochmuth. 1997. Knott's handbook for vegetable growers. 4th ed. J. Wiley and Sons, Inc., New York.

Maynard, D.N. and O.A. Lorenz. 1979a. Seventy-five years of progress in the nutrition of vegetable crops. HortScience 14:355-358.

Maynard, D.N. and O.A. Lorenz. 1979b. Controlled-release fertilizers for horticultural crops. Hort. Rev. 1:79-140.

Mehlich, A. 1953. Determination of P, Ca, Mg, K, Na, and NH4 by North Carolina soil testing laboratories. N.C. Soil Test Div. mimeo, N.C. Dept. Agr., Raleigh.

Myers, J.M. and D.S. Harrison. 1973. Drip irrigation of tree crops: distribution systems and design criteria. Proc. Fla. State Hort. Soc. 86:66-71.

Olson, R.A., K.D. Frank, P.H. Grabouski, and G.W. Rehm. 1982. Economic and agronomic impacts of varied philosophies of soil testing. Agron. J. 74:
492-499.

Phene, C.J. and O.W. Beale. 1976. High frequency irrigation for water and nutrient management in humid regions. Soil Sci. Soc. Amer. J. 40:430-436.

Phene, C.J., J.L. Fouss, and D.C. Sanders. 1979. Water-nutrient-herbicide management of potatoes with trickle irrigation. Amer. Potato J. 56:51-59.

Pier, J.W. and T.A. Doerge. 1995. Concurrent evaluation of agronomic, economic, and environmental aspects of trickle-irrigated watermelon production. J. Environ. Qual. 24:79-86.

Prasad, M. and T.M. Spiers. 1985. Evaluation of a rapid method for plant sap nitrate analysis. Commun. Soil Sci. Plant Anal. 15:673-679.

Reisenauer, H.M. 1983. Soil and plant tissue testing in California. Univ. Calif. Bul. 1879

Rhoads, F.M., S.M. Olson, G.J. Hochmuth, and E.A. Hanlon. 1996. Yield and petiole sap nitrate levels of tomato with $\mathrm{N}$ rates applied preplant or fertigated. Soil Crop Sci. Fla. Proc. 55:9-12.

Rosen, C.J., M. Errebhi, and W. Wang. 1996. Testing petiole sap for nitrate and potassium: A comparison of several analytical procedures. HortScience 31: 1173-1176.

Sanchez, C.A., S. Swanson, and P.S. Porter. 1990. Banding Pto improve fertilizer use efficiency of lettuce. J. Amer. Soc. Hort. Sci. 115:581-584.

Schon, M.K., M.P. Compton, E. Bell, and I. Burns. 1994. Nitrogen concentrations affect pepper yield and leachate nitrate-nitrogen from rockwool culture. HortScience 29:1139-1142.

Simonne, E.E. and G.J. Hochmuth. 2002. Soil and fertilizer management for vegetable production in Florida, p. 3-14. In: S.M. Olson and D.N. Maynard (eds.). Vegetable production guide for Florida. Fla. Coop. Ext. Serv. Misc. Publ.

Soil and Plant Analysis Council. 1994. 1993 international symposium on soil testing and plant analysis: Precision nutrient management. Commun. Soil Sci. Plant Anal. 25(7-10):665-1889.

Sussman, M.R. and W.H. Gabelman. 1989. Genetic aspects of mineral nutrition: Future challenges and directions. HortScience 24:591-595.

Thompson, T.L. and T.A. Doerge. 1995. Nitrogen and water rates for subsurface trickle-irrigated romaine lettuce. HortScience 30:1233-1237.

Ward, A.F., L.F. Marciello, L. Carrara, and V.J. Luciano. 1980. Simultaneous determination of major, minor, and trace elements in agricultural and biological samples by inductively coupled argon plasma spectrometry. Spectrosc. Lett. 13:803-831.

Welch, N.C., K.B. Tyler, and D. Ririe. 1985. N rates and nitrapyrin influence on yields of Brussels sprouts, cabbage, cauliflower, and celery. HortScience 20:1110-1112.

Willcutts, J.F., A.R. Overman, G.J. Hochmuth, D.J. Cantliffe, and P. Soundy. 1998. A comparison of three mathematical models of response to applied nitrogen: A case study using lettuce. HortScience 33:833-836. 